\title{
APUNTES SOBRE \\ UNA NUEVA NARRATIVA COSTARRICENSE: GERARDO CESAR HURTADO
}

\author{
POR \\ NORY MOLINA Q. \\ Universidad Nacional, Costa Rica
}

Gerardo César Hurtado pertenece a una nueva generación de narradores costarricenses, jóvenes cuyas obras vieron la luz en la década de los setenta; a pesar de su juventud (nacido en Puerto Limón en 1949), su producción es amplia; su primera novela es Irazú (1972), con la que ganó el primer premio en el Certamen Cultural de Artes y Letras «Bachiller Rafael Osejo» en 1971; su segunda novela es Los parques, de 1975; del mismo año, Así en la vida como en la muerte, su tercera novela; la última, Los vencidos, con la que ganó el Premio Editorial Costa Rica de 1976, se publicó en 1977. Y tiene un libro de poesía, Verano luminoso, de 1973.

Además, la labor de traducción de Hurtado es notable. Ha traducido a Blake, Saint-John Perse, Eluard, Rimbaud y a Keats; tiene una edición antológica de Ezra Pound.

Inmerso en un mundo cambiante, cuyas repercusiones son evidentes en nuestro medio social, Gerardo César asume su posibilidad de escritor. Costa Rica, en la década del setenta, presencia

... la agonía de una estrategia de desarrollo económico y social cuyo eje lo constituía la industrialización sustitutiva de importaciones, y la búsqueda de una alternativa válida para el conjunto de la clase dominante. Esta estrategia había sido impulsada por el Partido Liberación Nacional, de tendencia social-demócarta moderada, bajo la influencia del pensamiento cepalino y la situación condicionante del Mercado Común Centroamericano ${ }^{1}$.

${ }^{1}$ Rojas Bolaños y otros, «Movimientos populares en Costa Rica 1975-1978». Ponencia presentada al IV Congreso Centroamericano de Sociología «Blas Real Espinares», Managua, Nicaragua, 1-5 de julio de 1980. 
Así, al entrar en crisis el modelo de la CEPAL durante esta década, surge una serie de problemas concomitantes a nivel social: una alta tasa de desempleo, un proceso de proletarización del campesinado, movimientos campesinos de carácter reivindicativo, movimientos populares en demanda de vivienda, invasión de tierras, surgimiento de barrios marginales. Todo esto acompañado de una mayor labor organizativa de los partidos de izquierda y de los sindicatos. Se da, por lo tanto, en estos años una gran movilización a nivel popular y en ascenso del movimiento obrero y campesino en general ${ }^{2}$.

Una mayor apertura hacia las organizaciones populares, producto de una modificación de la conciencia nacional en relación con las condiciones materiales que la sustentan, provocó innumerables reacciones; en la década anterior tenemos ya antecedentes:

Las luchas del movimiento sindical bananero no quedaron circunscritas al carácter antipatronal. Estuvieron vinculadas con las del resto del movimiento sindical clasista dirigido por la C. G. T. C. y del movimiento obrero, con las luchas políticas del P.V.D., sus aliados en el plano electoral y los parlamentarios de los partidos progresistas; con las protestas comunales y las reivindicaciones agrarias del movimiento campesino. Internacionalmente, expresó la solidaridad con el movimiento de Liberación anticolonial y antiimperialista en América Latina; con las de la clase obrera mundial y particularmente con la Revolución Cubana... [...] Así esta huelga «se suma a un conjunto de luchas del movimiento obrero nacional, desarrolladas de manera ascendente a partir de 1965, y acentuadas al final de la década en el marco de una nueva crisis económica manifiesta hacia $1968 »^{3}$.

Es notable, entonces, que la Costa Rica de la década del setenta está viviendo importantes cambios a nivel social y a nivel político, generados también desde lo que José Luis Vega Carballo ha llamado un «Estado proteccionista constituido en 'manager' de la economía (que ha generado también) múltiples y novedosas posibilidades lucrativas para numerosos y fastuosos 'nuevos ricos'»"

En un marco tan controversial, Gerardo César Hurtado propone un nuevo acercamiento a esa realidad que permea toda la visión del mundo.

${ }^{2}$ Cfr. Judith Peña Martínez, «El movimiento obrero en Costa Rica en los años 1970-1978», Tesis U. C. R., Escuela de Historia, 1982, p. 200.

${ }^{3}$ Carlos Abarca Vásquez, «El sindicalismo bananero del Pacífico Sur en la década del 60», Nuevo Humanismo, C. E. G., núm. 5, Heredia, 1984, p. 96.

${ }^{4}$ José Luis Vega Carballo, Poder politico y democracia en Costa Rica (San José: Editorial Porvenir, 1982), p. 54. 
Estos apuntes pretenden una visión panorámica sobre la obra de Hurtado y el señalamiento de algunas de sus aportaciones al género novelesco costarricense, desde una contextualización histórica que permita una mejor comprensión del hecho literario.

Cuatro puntos básicos nos hemos propuesto señalar aquí como aportaciones de Hurtado a la narrativa costarricense:

1. La renovación a nivel del lenguaje.

2. La renovación en la contextualización histórica.

3. La honda criticidad, y

4. La desmitificación propuesta.

Creemos, sin embargo, que de sus cuatro novelas la más lograda es Así en la vida como en la muerte ${ }^{5}$, puesto que en ella confluyen, de una manera más desarrollada, los tópicos, los leit-motiv, los temas y las técnicas que muestra el autor en toda su producción. De aquí que le dedicaremos mayor atención a esta obra, desde los cuatro hilos conductores que hemos propuesto, y señalaremos, al mismo tiempo, las posibles conexiones con las obras.

Una de las aportaciones de Hurtado a la literatura costarricense en general y a la narrativa en particular es la renovación al nivel del lenguaje. Incursiona, a veces de una forma intempestiva, en las nuevas, por lo menos en nuestro medio, formas de novelar. Hay en Hurtado una búsqueda constante de nuevas imágenes, a veces alucinantes, a veces totalmente referenciales, que se pueden concentrar en una doble vertiente. Primero, en la polifonía, la lograda en las múltiples voces de la novela y que se plantea con un narrador totalmente moderno. Veamos.

Ya en Irazú, su primera novela, y que se podría señalar como una alucinante síntesis de imágenes entre las que se destaca la del Irazú (nuestro volcán) como símbolo de fortaleza, posesión y aniquilamiento sobre el hombre, la figura majestuosa del volcán domina toda la obra y permite una constante homología con la vida humana, en la que la opresión y la solidaridad van de la mano. Veamos un ejemplo de esta novela, en la que, desde un presente, se recuerda:

«E1 volcán riega su sangre», dijiste, Flora, alguna vez; ahora que la contemplación se vuelve lejana y estamos uno del otro tan separados que, difícilmente, el mundo nos reuniría por segunda vez: sería cuando el volcán apacible como hoy irrumpiera en lo sereno del país y provocara su caos infinito ${ }^{6}$.

${ }^{5}$ Gerardo César Hurtado (San José: EDUCA, 1975), p. 284. En adelante sólo señalaremos un número de página.

- Gerardo César Hurtado, Irazú (San José: Editorial Costa Rica, 1972). 
Este paralelismo, volcán-hombre, alcanza otros niveles de la obra, que va conformando una especie de novela paralela, ficción dentro de la ficción, rasgo que además es relevante en toda la producción de Hurtado:

Qué risa me da: todos ustedes se engañan, no estoy ni vivo ni muerto, no tengo complejos existenciales, no creo en elutivas inventadas por los Inquisidores, creo en otra cosa: en el mundo paralelo a éste, ¿no creen? ¿No puede un hombre caminar igual que yo hacia la cumbre, en un volcán idéntico a éste que vomita piedras? (pp. 103-104).

Es particularmente notoria la polifonía en la novela Así en la vida como en la muerte, que, como ya dijimos, reúne las posibilidades narrativas de este escritor. Hay en esta obra un narrador omnisciente, que parece sostener un doble relato, y que penetra la conciencia de sus personajes como un narrador tradicional; $y$, como otro narrador omnisciente (¿coincidencia de escritura?), va ampliando la visión del mundo de los personajes, en una especie de complemento del primero. Veámoslo en el texto:

Frunce el entrecejo Lucas y parece cavilar en tanto sus pasos se vierten por el polvoriente asfalto.

(La pregunta a sí mismo: ¿estaré en casa?)

Especie de plano con proyecciones iguales, contaminado de mundos de basuras (p. 13).

Además, este doble narrador omnisciente traslada su relato hacia los niveles del monólogo interior directo, en algunos casos, y en otros hacia la asunción del discurso como tal, con el narrador protagonista.

Un ejemplo del texto nos mostrará claramente esta utilización técnica:

- ¿Estoy muerto? — decía sin dejar de preguntárselo-. Reía el cantinero, para indicarle que no era nada, simplemente una broma.

Todo estalla, todo quieto. Muriéndose en el olvido voluntario o inexistente de las horas lentas. Mudez en el espacio solitario. Estar bajo tierra; ese, ese es el significado latente (p. 64).

Y otro más:

$Y$ sus cuerpos juntos entre las sensaciones infinitas de muerte dulce, entre el regreso de estrellas a campo abierto en los días festivos o de guardar sin importarle a nadie lo que hacían mientras corrían por el campo, recibiendo la brisa frecuente venida y desnuda sonora y débil, de los árboles que parecían venturosos y sin tristeza: los dos, Eunice y Jorge, recordándose, recordándome cuando afloramos el sudor de la 
piel y reímos y alzamos los brazos, alzaste los brazos, entornamos los ojos, así lo hiciste mientras yo te besaba en el cuello, tú me besabas en el cuello (p. 85).

Esta polifonía en la obra de Hurtado, múltiples voces que se entremezclan, se agolpan, se imbrican, produce un nuevo efecto: el manejo del aspecto témporo-espacial, que podría entenderse como otra aportación al género novelesco costarricense. Hemos dicho ya que desde un doble narrador omnisciente, Así en la vida como en la muepte presenta dos relatos desarrollados en forma paralela, que ubican, por un lado, a los personajes en su contexto histórico y, por otro, desde su interioridad. Veámoslo en la obra:

... un túnel lúgubre, tenía que apagar la linterna y sofocarse en la oscuridad arrebatadora, lejos de las legañas de los pantanos y los misteriosos cantos, como un soñar afiebrado de los sapos, miles de ellos entristeciendo el barro, el paso y su rostro (cada vez más atrás, años en el olvido, atrás, atrás, hasta la violencia del aire, atrás, un hombre cruzaba la cordillera central hacia el sur, por esos rumbos de ríos y poblaciones indígenas, en la cordillera de Talamanca, o devolviéndose hacia los valles, antes llamados de Santa Ana y Aguacate, cerros y hondonadas... (p. 222).

Este texto nos ilustra sobre el manejo de lo espacial y lo temporal en el autor. Un narrador omnisciente que viene relatando la historia de uno de los personajes (Lucas) en una cercanía temporal al presente, y muy cerca, en Puerto Limón. Sin embargo, este relato se imbrica con otro, que pertenece a la historia del padre de Lucas. Otro momento, otro lugar: principios de siglo, Valle La Estrella. Esto permite un desarrollo paralelo de las historias de los personajes, que logran completarse al final de la obra. Además, cada paso propone un acercamiento cada vez mayor de la conciencia de los personajes a la visión del mundo desde su condición de clase. Entonces, la imbricación narrativa nos va a posibilitar tambiến una doble perspectiva con respecto a los personajes.

El segundo aspecto importante en la narrativa de Hurtado lo constituye la renovación en la contextualización histórica. Cada novela propone, de manera particular, una revisión de la historia de Costa Rica, desde ángulos no «oficiales»; esto es, una recuperación histórica totalmente «interesada» o, llamando a las cosas por su nombre, «desideologizada».

Los vencidos, por ejemplo, plantea como nudo central el crimen del Codo del Diablo, ocurrido en la Guerra Civil de Costa Rica durante marzo-abril de 1948. Pero no en la versión oficial del acontecimiento, 
sino dentro de la ficcionalidad novelesca, donde se corren los velos de los hechos verídicos. Así,

... Federico respira agitado, le duelen las manos atrás, por la posición, al estar esposado, y trata de comer lo más que puede. Los otros hombres lo siguen atrás, y dicen y murmuran, es una trampa, es una trampa: sus ojos tienen un tinte desesperado. Ordenes son órdenes, $\mathrm{Ca}$ pitán, oyen un resguardo de peligro la voz tenebrosa del Capitán... [...] Hay un rumor, un chasquido ahonda sobre el Valle, abajo, en los precipicios y adelante, en el camino de Tizuadas rocas el Capitán dispara $^{7}$.

En Así en la vida como en la muerte se realiza la revisión de la historia de Costa Rica desde principios de siglo hasta nuestros días. Así tenemos el hallazgo del oro en el Valle La Estrella:

Deben estar en esos sitios, son unos peñascos enormes, sale agua ahí; ahí nace el río Estrella, él con sus propios ojos, lo había visto: vetas relucientes por el sol, cubiertas de lana... (p. 226).

Cada personaje va cubriendo tun trozo de la historia costarricense y por su participación adquiere relevancia ficcional. Los padres de Eunice hicieron su dinero trabajando una finca en el Valle La Estrella entre 1930 y 1940 . Se reconstruye así una etapa de nuestra historia en una zona inhóspita, poco conocida, pero que al mismo tiempo favorecía unas relaciones humanas más íntegras.

Por otro lado, el padre de Mónica participa en la Guerra Civil del 48, y su alusión como collage, una carta recordada, muestra las huellas que tal situación produjo en los costarricenses.

Además, los personajes más importantes (Lucas, Daniel, Eunice, Jorge) nacieron después del 48 , hecho importante en la medida en que señala nuevas vivencias de una generación que se inicia con los cambios de tipo político y económico que la lucha armada, ganada por el Partido Liberación Nacional, propició.

Es importante aclarar que la historia es asumida por su vigencia en la actualidad, ya no por añoranza del pasado. Pero debemos añadir, sin embargo, que los conflictos históricos del país se ven mediatizados por los conflictos eminentemente existenciales de los personajes. p. 168 .

${ }^{7}$ Gerardo César Hurtado, Los vencidos (San José: Editorial Costa Rica, 1977), 
Un ejemplo de Los vencidos nos puede ilustrar tal situación:

Feliciano veía en todo este tiempo ya olvidado (recordaba ahora, como si las imágenes fueran remotas, intocables, como detrás de una impenetrable barrera que era el tiempo y sus manos trataran de alcanzar, pero cuando lo lograban sentía que esas presencias se convertían como por una invocación ya real, ya mágica en cenizas, en un polvo muy fino que se desmoronaba como polen de flores en su memoria, un regreso a sus propios orígenes como la búsqueda de una explicación de sí mismo (p. 209).

Una derivación de este recorrido histórico es la profunda crítica, propia del género novelesco, que pone en juego este escritor.

Así, los valores y tradiciones se ponen en tela de juicio en todas sus novelas:

Yo no tengo moral, ni me interesa, ni la profeso 8 .

Estrepitosamente hundidos y aturdidos por la politiquería...

-A la mierda con la política -dice Octavio-; deberíamos preocuparnos por una vida mejor, por las plumas de los gallos, las muchachas bonitas ${ }^{9}$.

Todo esto es un círculo de unos cuantos hombres que sabemos pensar en la medida que todo tenga su arreglo, bueno o malo, sucio o corrupto. A nuestro círculo nadie entra. Ningún harapiento de esos que abundan por el Mercado Central o un pobre aspirante de clase media, que venga con sus pretensiones numerosas y desagradables, podrá quitarnos a nosotros (a mí) de nuestra posición, somos los únicos capaces de dirigir el pensamiento crítico de la sociedad costarricense, sociedad que está como está, por nosotros ${ }^{10}$.

Como producto de una generación desengañada - los personajes más importantes de Hurtado en todas sus obras, como ya hemos señalado, podrán tener entre veinticuatro y cuarenta años ahora-, muestran ya un total descreimiento de las posibilidades que el Estado pueda brindar al pueblo costarricense, como bien se afirma a través de Así en la vida como en la muerte:

... en este país no hay respuesta porque las preguntas han nacido muertas, todos nos estamos hundiendo... (p. 265).

${ }^{8}$ Hurtado, Asi en la vida como en la muerte, p. 218.

9 Hurtado, Los vencidos, p. 152.

${ }^{10}$ Hurtado, Los parques, p. 47. 
... ¿no era horrible?, ¿verdad que no parece Costa Rica?, dicen los anuncios, las radios, los locutores desbandados... [...] es noticia para los estómagos hambrientos... [...] es noticias al público, ¿no las oyeron, verdad que aquí es una Suiza? Y más allá abajo, golpeado, me golpearon como nunca, nunca pasa nada aquí, hoy se estrenarán no es cierto, no parece esta su Costa Rica, ¿verdad? (p. 265).

También en Los vencidos se expresa esta visión desengañada de lo nacional:

-Sí, aquí nos olvidan — se detuvo, hizo un resoplido leve, como cansado, entre sorpresa y preocupación-; las cosas en este lugar se olvidan, como si no nos conociéramos unos a otros.

-Así es nuestra nación, así es nuestro pueblo.

-Un lugar para resignarse a morir.

-Lo que necesitan estos carajos — señaló Miguel el horizonte: una raya rojiza apenas entrevista en sombras y movimientos sigilosos de lo nocturno - y discúlpame la palabra - volvió a señalar, como si hubiera alguien, una multitud fantasmal a su frente es una inyección de valor. Que se quiten los anteojos de la mediocridad (p. 115).

Así, los personajes de Hurtado no sólo muestran un descreimiento, sino que van aún más allá y señalan, en todo su patetismo, la cruda realidad costarricense. Ni siquiera el modelo económico, implantado en la década anterior, es alentador; ya se ha puesto a prueba, y lo que deja es sólo la esperanza en la lucha por las reivindicaciones sociales y la amarga enseñanza de la represión brutal, como lo expresa el narrador de Irazú:

Ese profesor, si te fijas bien, soy yo, que después de vivir en tinieblas y soñar y vivir en una casa oscura, renunció del mundo y luchó por los oprimidos como otros lo hicieron: escribieron cartas a los gobiernos para proclamar su liberación (p. 117).

Dentro de esta tendencia, es necesario señalar en las obras de Hurtado un marcado antiimperialismo, que lo ubica dentro de una corriente de toma de conciencia que tiene sus orígenes a principios de siglo en nuestro país. El antiimperialismo en este autor se pone en evidencia alrededor de las luchas populares que tuvieron lugar en contra del establecimiento de la A. L.C. O. A. en Costa Rica, por los años setenta.

El personaje más importante de Los parques participa activamente en tal lucha:

Se sabe -información conseguida a través de los archivos de periódicos- que fue el que en 1970 participó en la marcha de protesta frente a la Asamblea Legislativa, contra el Proyecto de A. L. C. O. A. 
Gritó, tiró piedras, rompió vidrios y ventanas, incendió un automóvil de un Diputado; huyó por las calles ante los gases lacrimógenos. Fue apresado y vapuleado, torturado por gracia de Dios... (p. 144).

Además, en Así en la vida como en la muerte la lucha contra la A. L. C. O. A. se constituye en uno de los acontecimientos fundamentales de la novela y en ella interviene también Lucas, uno de sus personajes más importantes. Hay una variante muy interesante: la participación de Lucas se entremezcla con la figura del héroe nacional Juan Santamaría, quien luchó contra William Walker y sus filibusteros, que pretendía apoderarse de Centroamérica en 1856. Ahora bien, esta ubicación refuerza la causa que defiende la perspectiva global de la novela: su antiimperialismo. La situación histórica del héroe y los ideales que él representa se comparan con la situación contemporánea:

-Voy —dijo Lucas-. No podemos seguir aguantando el agua de los pozos podridos. Necesitamos que esto se detenga, que el contrato con esa compañía caiga por sta peso.

Izaron banderas, los uniformes se mezclaron con el polvo de la calle y el calor pálido del firmamento. Desde ese momento sudaban, entre las idas y venidas de la policía, apretados unos contra otros. La muchedumbre de estudiantes se levantó con un cartelón: «Queremos un contrato nuevo. ¿No hipotecaría el futuro de nuestros hijos?» (Entonces estaban frente a la estatua del héroe con fusil, viéndolo interrogar a los árboles, viéndolo descalzo con una tea en la izquierda y el rifle en la derecha avanzando invisible por entre las barreras de sacos de arena para adelantar sus pasos hacia un hombre alto, de gorra café) (p. 176).

E1 otro aspecto de la producción de Hurtado, y que plantea agudamente, es la desmitificación de una serie de valores tradicionales de una sociedad, ya en crisis permanente, que no ofrece expectativas para el desarrollo pleno del ser humano.

Asî tenemos que, al nivel de los personajes, aparecen rasgos muy significativos que promueven una desmitificación en una doble perspectiva:

- A nivel social, los personajes pertenecen a las capas sociales más bajas, sobre todo en Así en la vida como en la muerte.

- Lucas, el personaje masculino más importante, es contrabandista y traficante de drogas.

- Mojarre es mendigo.

- Eunice es bailarina de clubes nocturnos.

- El personaje más importante de Los vencidos es doblemente criminal: mató a Héctor Figueroa y participó en el crimen del Codo del Diablo. 
Todos ellos muestran la desmitificación de la sociedad en que vivimos: son su producto y encierran todas sus contradicciones. Son, además, la concreción de las lacras sociales que arrastramos. En este sentido, podríamos señalar que la obra de Hurtado es posiblemente la mostración de lo que 1lamaríamos «productos de anti-cultura», como opuestos a los productos de la cultura oficial. Por ello, el mundo se percibe como caótico, como no correcto, en contraposición con los valores culturales de un consumo ya establecido socialmente, tal como se expresa un personaje de Asi en la vida como en la muerte:

- Ah pues, hace tiempo que la fumo - decía-; antes la traficaba. Desde Panamá a Nicaragua. La sembrábamos y la poníamos en papel celofán, entre latas de conservas (p. 144).

Los personajes, por su misma extracción social, contravienen todos los cánones «culturales» y esto le confiere a las obras un hondo contenido clasista. Es significativo, también, que muchos de ellos son partícipes de una toma de conciencia muy propia de la Costa Rica de los años sesenta y setenta.

Ahora bien, hemos dicho que Hurtado, en toda su producción -a través de sus personajes - propone una desmitificación en una doble perspectiva. Creemos que el otro nivel que desmitifica es el individual. Los personajes de más baja extracción son, sin embargo, más auténticos y, por eso, más humanos. La figura femenina, en toda la producción de Hurtado, es relevante a este nivel significativo: las mujeres encontrarán su autenticidad en el abandono de todos los convencionalismos. Además, se presentan como posibilitadores de relaciones auténticas reivindicadas en el amor y la sensualidad. En Los parques, el personaje femenino Teresa se evoca así:

... y en el fondo del mismo la evocaba como una mujer fabulosa que me llamara desde el fondo de un abismo, desde la profundidad más etérea a la altura más elevada, era cuando la llamaba como si surgiera volando de una embriaguez desde una locura sin conocimiento y como si me rescatase de un lugar solitario y frío (p. 88).

Eunice, el personaje femenino de Así en la vida como en la muerte, resume toda la temática amorosa de Hurtado. Su imagen, auténticamente erótica, sirve para tratar en forma descarnada un leit-motiv en la obra de este autor: el adulterio y el incesto. Sin embargo, es el amor el que posibilita toda relación sensual y, en este sentido, los personajes encuentran su cauce y su razón de ser. Las imágenes eróticas son constantes: 
Sus manos, sus ojos, su cuerpo, su dolor allí en el centro de la carne. En la adoración del movimiento cuando se extiende una caricia lenta. E1 apenas la tocó, sin distinguirla... [...] Uno y otro cuerpo se llamaban por los abrazos angustiantes, llenos de sudor y presiones tremendas en las caderas. Daniel sentía que las horas se le acababan en ese momento. Pero su amor, ese que sentía con profundidad, algo así como un vínculo demasiado espiritual y carnal, se aflojaba, agotado, ya lo sabía (p. 68).

La sensualidad de los personajes se da siempre en una relación eminentemente amorosa, lo que permite el encuentro con valores humanos auténticos.

Hemos señalado, en estos apuntes, algunos elementos de la obra de Gerardo César Hurtado que creemos constituyen aportaciones de este escritor a la novela costarricense.

A nivel del lenguaje, la utilización de un narrador totalmente contemporáneo le ha permitido una doble perspectiva: la interiorización a la conciencia de sus personajes y su contextualización histórica. Esto, a su vez, ha posibilitado una recuperación de la historia, no como añoranza, sino por su vigencia en los conflictos actuales. Además, tales elementos involucran una severa crítica en cuanto a la percepción de la realidad, en la que adquiere gran relevancia el antiimperialismo vigente en toda su producción. Este enfrentamiento con una realidad no congruente con las necesidades básicas del ser humano le han abierto la puerta para una desmitificación profunda de ciertos valores tradicionales de la sociedad costarricense. 
